\title{
An Overview of the Phenomenon of Waiting in the Class from the Perspective of the Classroom Teacher: A Phenomenology Study
}

\author{
İbrahim Akar* \\ Dept. of Educational Sciences, Kastamonu University, Kastamonu, Turkey \\ ORCID: 0000-0001-5147-129X
}

Article history

Received:

8.01.2020

Received in revised form: 02.04.2020

Accepted: 05.04.2020

Key words:

Giftedness, gifted education, inclusion of the gifted, classroom teacher, waiting in the class
The purpose of this study was to reveal the reasons and different factors underlying the phenomenon of waiting in the class based on the opinions and experiences of classroom teachers teaching gifted students in the regular classrooms. The study was conducted as a phenomenology study, which is amongst qualitative research designs. The participants consisted of four classroom teachers teaching in regular classrooms including gifted students at a public elementary school. A series of open-ended questions developed by the researcher focusing on the phenomenon of waiting in the class were asked to the participants and responses received. Interviews with each of the participants were guided by a semi-structured interview protocol. Data were subjected to content analysis using a qualitative analysis program. Analysis of the qualitative data revealed nineteen different codes under four different themes. The themes emerged after the analysis were: state of the classroom, intra-course routines, nature of being gifted and teacher's competence. In conclusion, gifted students' waiting in the class also existed in elementary school classrooms and the reasons of the phenomenon differed from the perspective of the classroom teacher. Before the beginning of the process of supporting gifted students in regular classrooms, there is a need to implement a number of specific measures to overcome the issue.

\section{Introduction}

Gifted students, in most cases, are one of the members of the regular classrooms, yet with different educational needs. However, unlike other students in the classroom, gifted students face with unchallenging curriculums, teaching at a slow pace, and even teachers' ignorance (Berman, Schultz \& Weber, 2012). Moreover, adversities such as the repetition of what is already known, the emphasis on scientific facts rather than thinking skills, the inability to progress in the curriculum after mastering the general curriculum and insufficient study opportunities in interested areas lead to a curriculum with a lack of challenge (Gallagher, Harradine \& Coleman, 1997). Nonetheless, these students perceive regular classrooms more positively than their peers do (Yang, Gentry \& Choi, 2012). Naturally, they spend a considerable amount of time in general education classes like any other student, and expect their educational needs to be met like everyone else.

\footnotetext{
*Correspondence: iakar@kastamonu.edu.tr, brhmkr@gmail.com
} 
Coping with gifted students in regular education environments is a critical situation in the education of these students. Along with other teachers, this is of particular importance for classroom teachers. In support of this, according to a research finding, elementary gifted students prefer to be educated in different environments with different teaching styles and they prefer a robot or a computer instead of a teacher because of not getting any individual support from their teachers (Armstrong, 1995). According to Sisk (2009), this is independently a myth and a fact that a classroom teacher copes with a gifted student. She emphasized that, even if the classroom teacher can implement differentiation, there is a need for a school culture and a belief system that supports the gifted and a willingness to include his/her needs in the curriculum of the gifted. Any lack of these factors will also cause the gifted student to sit and wait in the classroom, in other words, to waste his/her time.

It is customary for students who study in regular education systems to sit in the classroom and wait and this does not only pertain to gifted students (Cullingford, 1991). Regardless of the level of education they are receiving, or whether any particular type of special need(s) affects them, some of the students in the class learn and finish tasks quickly, many of them complete it on time and some do not even complete the task. This is because even when considered in the context of academic achievement, it was found that the distribution of the range of students' achievements at a typical grade level was higher than five years/ages (Gagné, 2005). Teachers, while teaching, address the average student level or fit the majority (Gallagher, Harradine \& Coleman, 1997) and considering this does not happen in accordance with the educational level of many students; waiting may emerge before or after the teaching activities for students in the classroom and one can think that the gifted student will be affected differently. Furthermore, such an effect would force the gifted student to sit in the classroom and wait for others to learn (Peine, 2003), or to become a "lone learner". They may even develop problem behaviors when they have to get trained from teachers who do not enjoy teaching and learning with gifted students, do not offer compelling and complex educational options, or who do not facilitate learning opportunities with intellectually high-level peers like themselves (Delisle, Whitmore \& Ambrose, 1987).

It is possible to come across expressions regarding the educational measures, regulations and supports of special needs and gifted students educated within the Turkish Educational System in different legislations (MEB, 1956; 1961; 1973; 1997; 2006; 2012; 2013; 2014; 2016; 2017; $2018 \mathrm{a} ; 2018 \mathrm{~b})$. When the measures and regulations that directly or indirectly target the education of the gifted examined, it is seen that the aim was to support gifted students in the regular education process like other students with special needs. In sum, these measures, regulations and supports were addressed on several frameworks and through certain actions such as; the number of students with special needs will be placed in regular classrooms, individualized education practices, resource room education, full-time integration / inclusion practices, acceleration through grade skipping, flexibility in attendance, support by Science and Art Centers, transferring to secondary education institutions related to their ability, taking necessary measures for their education and vice versa. Nevertheless, at the beginning of each academic year, gifted students come to the school having internalized $35-40 \%$ to $55-60 \%$ of the curriculum for relevant grade (Coleman \& Cross, 2001; Ross, 1993). This means that a gifted student has the potential to be exposed to a phenomenon: to wait in the class, unless adequate and appropriate support is provided, and specific arrangements are made. 


\section{The Phenomenon of Waiting in the Class}

The phenomenon of waiting in the class, which has been revealed as a grounded theory towards this situation brought about by being gifted, takes place in these following three types: School/classroom waiting, instructional waiting and assignment waiting (Peine \& Coleman, 2010). The school/classroom waiting is linked to the organization of the classroom and the reasons for it are the management of student behaviors, classroom order, rules, classroom type and teaching model. For instance, the gifted student, in a teacher's classroom who sets a rule in the form of sitting and waiting silently after finishing the activity individually, will have "plenty of time to waste" during the lessons because of completing the task quickly. There should be a purpose of ordering and establishing rules, and these should include the creation of a space for students to move, ensure students to progress based on courses or curricula, and make use of the time well.

Instructional waiting is defined as the time taken during the demonstration or presentation of new material and things to learn, in the form of content or process during the course (Peine \& Coleman, 2010). Among the reasons of this type of waiting are preliminary knowledge about what to be taught or the material, understanding of the material and new knowledge very quickly, stop/slow down the progress of the course and finding the content of the course to be meaningful/meaningless. Waiting occurs when students already knew or learn quickly the material and what is being taught. Having said that when gifted students learn something new, they do not need as much time as other students. What is more, the wait time in relation to the previously possessed information, the presentation of the new concept and the repetition of the known ones is striking. The gifted student would find it boring when he/she was presented with what he/she already knew or when he/she began to repeat it. On the other hand, when he/she finds out that what is being taught is something that he/she already knows, he/she may likely expect for another task. Additively, waiting also occurs if other students ask questions with a view to fully grasping the relevant concepts, thereby stopping or slowing down the progress of the class.

Assignment waiting emerges as a consequence of long-term practices in a course where new content has been introduced or as a result of the students' own works on their desks (Peine \& Coleman, 2010). The situations that lead to this type of waiting are: completing the task very quickly, having completed all the work related to the course, use of inadequate technology, teachers' leisure time choices, and working on group assignments not based on collaborative learning. It is not surprising that the gifted student completes the task as well as all the studies related to the course subjects in quite a rapid fashion because for a gifted student, activities at the class level embedded in textbooks/workbooks may be quite easy. Thusly tasks, to be given for the gifted student who has the capacity to work and advance faster, must be well structured. In particular, it is expected that time will be devoted to independent applications/studies in the course content and tasks given after teaching will be structured with a focus on the specific student's talent(s).

Waiting in the class, which is explained in detail above, was grounded by working with gifted students from grades 1 to 8 . Having this said, investigating the experiences of teachers regarding this phenomenon will help reveal varying reasons underlying waiting in the class and will enable to evaluate the causes of the phenomenon from the perspective of the teacher. In this way, it will be possible to identify potential barriers arising from issues such as behavior and classroom management problems with regard to waiting in the class and will contribute to the creation of effective classroom climate and learning environments for the gifted student. Therefore, the purpose of the current study was specified as to uncover the 
different reasons underlying the phenomenon by investigating the experiences of classroom teachers who have gifted students in their classrooms. In this context, the main research problem of the current study was structured as "What are the experiences of classroom teachers who have gifted students in their classroom regarding the phenomenon of waiting in the class?".

\section{Methodology}

\section{Research Design}

The purpose of this phenomenology research is to understand the experiences of classroom teachers with gifted students in their classrooms, who continue their teaching/learning activities at elementary level. Phenomenological research is carried out to understand the lived experience(s) of a person or individuals towards a phenomenon (Creswell, 2013). Correspondingly, this research tried to understand how classroom teachers of elementary gifted students experience waiting in the class as a phenomenon and how they describe the reasons that cause the phenomenon. To that end, views of each classroom teachers were evaluated free from any prejudices.

\section{Setting}

The elementary school, in which this current research carried out, was established eighty-five years ago. The school is known as a historical and well-established school in its province. The school's management and training staff consists of highly experienced people. A total of six hundred and ten students are being educated by twenty teachers in seventeen classrooms at the school. There are eleven students at the school identified as gifted. The educational activities of these students are provided through differentiation and enrichment according to their developmental and academic levels. The researcher was invited to this school to contribute to the differentiation and enrichment activities for the gifted students. With this invitation, the researcher advises teachers on the programs applied to gifted students and provides support in line with the action plan. The interviews conducted within the scope of this research constitute a certain part of the preparatory phase prior to the commencement of this process.

\section{Participants}

The participants of this current study consisted of four in-service classroom teachers of a public elementary school who have gifted students in their regular classrooms. These teachers were teaching second, third and fourth grade students. More information about these teachers is given below.

\section{Classroom Teacher 1 (CT1)}

The fourth grade teacher is a female. She has a gifted student in her classroom who was categorized in general talent field. She has been working as a classroom teacher for twenty-nine years. The total number of students in her classroom is thirty-one. Among the students in the classroom and apart from the gifted one, there is a student who is not formally recognized as one with special needs but they seem to fall behind the grade level. 


\section{Classroom Teacher 2 (CT2)}

The third grade teacher is a female. She has four gifted students in her classroom. Two of them were identified to be within general talent field and other two were situated in special talent fields (music, visual arts). She has been working as a classroom teacher for thirty-four years. The total number of students in her classroom is thirty. Among the students in the class and apart from the gifted ones, there is a student diagnosed with language and speech disorders.

\section{Classroom Teacher 3 (CT3)}

The second grade teacher is a male. He has three gifted students in his classroom. All of them were identified to be in general talent field. He has been working as a classroom teacher for thirty-two years. The total number of students in his classroom is thirty-seven. Among the students in the class and apart from the gifted ones, there are students who are not formally identified as such but are behind the grade level.

\section{Classroom Teacher 4 (CT4)}

The second grade teacher is a female. She has a gifted student in her classroom that was identified to be in general talent field. She has been working as a classroom teacher for twenty-eight years. The total number of students in her classroom is thirty-seven.

\section{Data Collection, Data Analysis \& Ethics}

The data of this current study consisted of the answers obtained from a series of openended questions directed to the participants about their views and experiences on the phenomenon of waiting in the class via the semi-structured interview protocol. Interview questions were developed depending on the three types of waiting and each type included four or five main questions with probes and follow-ups. For instance, some interview questions through which the participants were asked about school/classroom waiting were: "What do you think about your classroom type in terms of teaching the gifted student in the regular classroom? Why? How is your classroom arrangement? Please describe in details. What do you mean by...? Can you expand it more? etc...

Prior to the data collection process, it was reported that a regular meeting with each of the participant teachers would be conducted both for a description of the situation in the school and for this research study. Participation was made on a voluntary basis. Each interview lasted approximately 40 minutes. The researcher himself conducted the interviews with the teachers as he is the one that recognized by the teachers who supports them as a consultant in their educational activities in school. In this way, the possibility of teachers' not giving sincere answers during the interview by feeling anxious or being under pressure is eliminated. The collected data were transcribed and transferred to Maxqda analysis program and subjected to a content analysis. With the content analysis, qualitative data of the research were systematically coded and themes were created.

\section{Credibility \& Honesty}

In this research, triangulation technique was used to provide credibility. Triangulation brings multiple and different sources together to provide evidence supporting the phenomenon or case (Creswell, 2013). In this study, data were collected from three different classes: second, third and fourth grades. First grades were not included because the process of 
nomination and identification of gifted students based on the relevant legislation of MEB (2016; 2018a; 2018b) begins in the spring term in first, second and third grades and the identification process ends in summer months. This shows that it is only possible for a student at the first grade, to return back to the school recognized officially as gifted in the second grade. In order to support triangulation, one of the experts in giftedness was appointed as an external observer during the analysis. The researcher received the opinions of the external observer in the analysis process. Besides, the researcher re-analyzed all the data two months after the first analysis and the external observer was consulted again. The external observer was also asked to create codes and themes. The Kappa coefficient of agreement (Cohen, 1960) between the researcher and the external observer was determined as .85. This coefficient shows a strong consistency between the researcher and the external observer (McHugh, 2012).

\section{Findings}

Four themes were created as a result of the analysis of the interviews with classroom teachers who were the participants. Each of these themes contains different codes (Table 1). The theme of the state of the classroom comprised of codes such as; overcrowded class in a poor physical environment, different student levels, and dual education. The theme of the interclass routines includes codes such as; becoming activated, course content and assessment. The theme of the nature of being gifted consists of codes such as early finishing, self-distraction, boredom, perfectionism, differences brought about by talent, and rapid learning. The last theme, the teacher's competence, involves codes such as; improvisations, knowledge-orientedness, lack of motivation, individualization, grouping, teaching model and polling the preliminary knowledge. Findings were reported using these four themes.

Table 1. Meaningful clusters that were developed into themes

\begin{tabular}{ll}
\hline Themes & Codes \\
\hline State of the classroom & Overcrowded classes in a poor physical environment \\
& Different student levels \\
Dual education \\
Intracourse routines & Becoming activated \\
& Course content \\
Nature of being gifted & Essessment \\
& Early finishing \\
& Boredistraction \\
& Perfectionism \\
Teacher's competence & Differences brought about by talent \\
& Rapid learning \\
Improvisations \\
Knowledge-orientedness \\
Lack of motivation \\
Individualization \\
Grouping \\
Teaching model \\
Polling the preliminary knowledge
\end{tabular}

\section{Theme 1: State of the Classroom}

Different views were obtained from the participants under the theme of the state of the classroom. The participants' views were placed under three different codes. These include overcrowded classes in a poor physical environment, different student levels, and dual education. 


\section{Overcrowded Classes in a Poor Physical Environment}

During the interviews with the classroom teachers, it was revealed that the class sizes had a negative impact on supporting the gifted students. What is more, the physical inadequacy of the classroom also affects the overall process negatively. Teachers emphasized that alongside physical inadequacy in the classroom and school, the overcrowded class caused waiting in the classroom.

(The size of my class) I do not think it's appropriate. I have 37 students in my class. It is both an overcrowded and a physically cramped class. As there are many students, there are several level groups. [...] I can rarely do group work. This is due to the physical structure of the classroom and the lack of opportunities to work together outside the school. [CT3]

(My class) Is not suitable for teaching the gifted children. The number of students is 33 and it is very crowded; there is a congestion because of having too many student desks. [...] (Group works) I can do it in physical education and play classes, and during drama studies. It is not possible in other classes because I cannot change the seating arrangement. [CT1]

Our class type is not suitable for teaching the gifted children. Because I have 37 students in my class and it is too crowded. It is very difficult to create an environment in which we can show special attention and develop skills in the classroom. [...] For example, we do not have the opportunity to do group work in the classroom. The physical environment of the classroom is not suitable for this. [CT4]

\section{Different Student Levels}

Classroom teachers pointed out that there are students of different levels, which is a natural fact of classes. They stressed that this was an obstacle for the individual support of gifted students and has effects on waiting. Additionally, having more than one gifted student or student with special needs in their classes is articulated as another factor that causes waiting.

The ones who have problems in reading also struggle in problem solving. They cannot express themselves in the narrative and comprehension activities. I assign these students tasks of one-to-one nature or teach them individually while others are painting. [...] Each student's learning speed is different. But the whole class is moving at a common pace. This affects the process negatively. [CT3]

The students who grasp the subject are getting bored by the questions of the students who are not able to comprehend, and may (start) not be interested in the lesson or they may request to be asked difficult questions. [CT1]

\section{Dual Education}

One of the classroom teachers criticized the fact that the school in which they were teaching had dual education (a system in which the classroom is shared by two different classes such as one from morning to midday and the other from midday to evening). He pointed out that this prevented the formation of a classroom order as he wished to support the interests and abilities of the students. The teacher stressed that this situation is also a problem for the gifted students with respect to providing the necessary support to them. 
Although no changes can be made due to the physical structure of the classroom, the layout of the classroom cannot be touched at all because of the dual education system of the school. [CT2]

\section{Theme 2: Intracourse Routines}

Different views were obtained from the participants under the theme of interclass routines. The participants' views were placed under three different codes. These codes are becoming activated, course content and assessment.

\section{Becoming Activated}

Classroom teachers stated that students had to wait in varying periods to become activated in the classroom environments in which they were educated. According to two of the teachers, this period can vary from 10 to 25 minutes; but it is understood that a classroom teacher gives the students their tasks at the end of the lesson. It indicates that this situation taking place in environments where gifted students are also being educated turns out to be "waiting for a task" to become activated.

Depending on the nature of the subject, sometimes I assign students tasks immediately after the introduction stage; we discuss the subject together with the students. Sometimes I assign students tasks at the evaluation stage. [...] It can take up the first 10 minutes, depending on the subject matter. This may be because the issue does not attract the attention of the student or the teacher cannot foster motivation. [CT2]

At the end of the lesson, I give the students their tasks. Because this is when you are sure the lesson is understood... However, due to class size, this may take too much of the class time. This is not healthy. [CT3]

Individual studies vary according to the activity. Sometimes we do it in 10-15 minutes of the lesson. Sometimes it takes 20-25 minutes. [CT4]

\section{Course Content}

Classroom teachers stated that even if gifted students know what will be taught in the content of the courses, they still follow the course and the relevant teaching practices. Notwithstanding, teachers reported that gifted students did this so as not to disrupt the order of the course yet that they were bored for it was unchallenging for them to solve the same type of problems or reinforce activities, especially in mathematics, like the others. These situations indicated by the teachers make us think that the gifted student is experiencing the waiting indirectly by participating in the courses and tasks that do not address his/her own level because the content of the course cannot be differentiated as desired.

I give the tasks of the students in the development stage after motivating them. Sometimes I give them in conclusion and evaluation stages. I think they are better adapted in these sections. [...] Even if he knows (the content), he follows the class. I see him constantly following and attending the course. [CT1]

Even if they have mastered the content of the courses, they usually follow; I think they like to hear different examples. They may seem to be listening to keep the course in order. [...] They are bored of solving the same problems especially in mathematics classes. [...] They get bored of making sentences when answering text-related questions." [...] (Time spent demonstrating on what to teach) Depends on the method I use in 
teaching, $1 / 4$ of some courses are allocated to the students, while some of the courses can be allocated to the students by $3 / 4$. [CT2]

Sometimes I notice that the student is repeating what he already knows. I think it is good. It is a good thing to remember and learn about the past while gaining new knowledge. [...] They are not bored (during the course). This happens occasionally. Usually reinforcement activities can be unchallenging (to them). [CT3]

\section{Assessments}

It was understood that the evaluation of classroom teachers of the lessons taught could not go beyond general evaluations. Teachers pointed out that gifted students were also involved in the general evaluation stages but preferred to be inactive from time to time. This implies a lack of individual assessment and can be considered as a situation that forces them to sit and wait.

I do it very often. I do it for every learned subject. In order to plan how much of the subject is understood, how much I can tell, what more can I plan to do... [CT3]

I usually repeat my evaluations in the classroom. In order for the student to see his / her own mistakes and to correct himself/herself... (Gifted students) On the contrary, they get tired of checking it repeatedly. They prefer not to check, including reviews. [CT2]

I will definitely reevaluate an activity in the class. I will do it after the subject is covered. A few days a week. Because I can see how much of the aspects they understand of the activity. I will try to eliminate any deficiencies. [CT4]

\section{Theme 3: The Nature of Being Gifted}

Similar and different views from the participants were obtained under the theme the nature of being gifted. The participants' views were placed under six different codes. These codes are early finishing, self-distraction, boredom, perfectionism, differences brought about by talent, and rapid learning.

\section{Early Finishing}

The observations and statements of the classroom teachers indicated that gifted students complete the activities implemented in the classroom much earlier than the others and this is usually the case. It was stated that when they finish the task or activity earlier, they evaluate the remaining time with a similar activity or doing something they desire. However, since this is not structured with a focus on his/her talent, it may remain as a time-filler.

Since the activities are within the available MEB (The Ministry of National Education) resources, I do not conduct a preliminary audit. If I prepare the activity referring to some other sources, I value its suitability. [...] There are times when they finish these activities early. To rate it, it is like $25 \% \ldots$ [CT2]

Usually (they finish the activity early). Most of the time they come to me with this suggestion: "It's done! May I paint, read my book, etc... If they do not have any suggestions, I'll give them a different activity to be completed. [CT3]

I constantly observe that she finishes activities faster than others. When she is finished, I give her some backup activities. Because she gets bored until the others finish. She demands this herself. [CT4] 


\section{Boredom}

Classroom teachers stated that during the conduction of the activities that were unchallenging for them, these students had to repeat what they already knew and got bored while learning the subjects that were quite easy to them. This shows that the gifted student spends his/her time by trying to cope with the boredom instead of focusing on his/her talent development.

They do not get bored (in the class). This happens sometimes. Usually reinforcement activities can be unchallenging (to them). I try to prevent this by asking them questions. [CT3]

He does get bored in the class. The reason for this is either the repetition of what he has already learned (or which he already knew) or the fact that he is not interested in the topic. [CT1]

They are bored of solving the same problems specifically in mathematics classes. I want them to set up and solve a problem on their own. They get tired of making sentences while answering text questions. They give short answers like yes or no. [...] They deal with their own materials, though not very often, during the processing of topics they find unchallenging. [CT2]

I feel she gets bored while playing the flute in music class. I do not think she is bored in other classes. [CT4]

\section{Self-Distraction}

It is stated that gifted students check their activities repeatedly when they finish the task or activity early and/or use the activity sheets for different purposes. It was also found that when they had nothing to do, they spent their time dealing with their own materials or became engaged in painting. It is thought that this situation, which needs to be handled in advance, leads to waiting by directing the gifted to find engagements to distract himself/herself.

Yes, they check back over and over again. They do this to avoid mistakes. I tell them not to exaggerate. Because it's not normal for someone to perform the activity in 5 minutes and check it for 20 minutes. [...] She makes different drawings on the activity sheet or writes notes to me. It's OK. I don't frustrate her. [...] Yes, it (dealing with its own materials during class) happens when he/she has nothing to do. Sometimes I need to send a warning. [CT3]

She does not always work (With her own materials during the class). Sometimes I see her painting. I am not focusing on that because it does not happen so much. [...] Sometimes she does different things using the activity sheet. I ask her why she did that. Because I wonder why she did it. [CT4]

They deal with their own materials, though not very often, during the processing of topics they find unchallenging. I welcome that. It is important that they feel happy in the lessons. [...] They do different things like decorations, drawing different facial expressions and writing thanks messages for me. Not in a specific class, this can happen in any class. I greet them with a smile. I never thought of making sense of these. [CT2] 


\section{Perfectionism}

Classroom teachers observed that gifted students tried to reproduce their output/work and tended to check these repeatedly to avoid making mistakes. They even stated that the students erased what they wrote and started over from the beginning. Pure repetition of the tasks without being structured in accordance with their talent development is only something that the student chooses to do instead of waiting. It also leads to a negative evaluation of the perfectionism of the gifted.

One of my gifted students might not like the article he wrote at home and rewrote it at school. I did not consider it as a problem because it does not occur at a disturbing frequency. I asked why and he said he began writing not on time and wrote it because of the fear of not being able to complete his homework. [CT2]

Yes, they check back over and over again. They do this to eschew mistakes. I tell them not to exaggerate. Because it is not normal for someone to perform the activity in 5 minutes and check it for 20 minutes. [CT3]

He rubs it (what he wrote in class as part of the task) down and starts over again. And sometimes he edits it. [CT4]

\section{Differences Brought about by Talent}

It is witnessed that gifted students try to exhibit their talents by trying out different solutions and by dealing with the field they are capable of rather than the lesson itself. This means that instead of waiting in the classroom, they expect different tasks pertaining to what they are interested in or are capable of.

The students (gifted ones) in my class did not explicitly make any requests. They may have different ideas for problem solving. They can try different ways of solving mathematical problems. I saw that the student of the painting department (talented in visual arts) was drawing even in the shortest periods he caught. My reaction to this situation is positive. I also tell others that there may be personal differences. [CT2]

She looks for new ways to reach what he does not know. She is trying to find different solutions especially in mathematics classes. I see it normal. Curiosity is the basis of learning. I show her the ways to get to knowledge. Sometimes even the knowledge itself... [CT4]

\section{Rapid Learning}

One of the classroom teachers emphasized the unusual learning speed of gifted students. She also stated that this feature had negative implications for the other students' learning in the classroom. It can be noted that rapid learning, which is primarily associated with the gifted student and with other students in the second place, actually causes bilateral waiting.

Gifted students can learn in a narration, by a sample or only with a repetition. I sense that some students develop jealousy. In this case, the students of the class who learn at a relatively lower pace (five students in my class) become disadvantaged. Sometimes they may not have enough time to perform the task to learn. [CT2] 


\section{Theme 4: Teacher's Competence}

Different views were obtained from the participants under the theme of teacher's competence. These views of the participants were placed under eight different codes. These are improvisations, knowledge-orientedness, lack of motivation, individualization, grouping, teaching model and polling the preliminary knowledge.

\section{Improvisations}

Classroom teachers emphasized that they set research tasks, in-class tasks (library tasks, clipboard etc.), spare type of activities, reinforcement and repetition tasks, design works for gifted students and they allow them to do what they want, or they try to prevent them from getting bored by posing several questions. Two of the classroom teachers stated that they try to provide independent work opportunities, even if these were not very frequent or only during leisure time activities. Together with that, it can be uttered that these practices are not well structured with a focus on talent development and may lead to the phenomenon of waiting.

When she has finished (the activity), I give her some backup activities. Because she gets bored until the others finish. She asks for these activities herself. I give in-class tasks out of class. Such as bookcase, clipboard, etc. I also provide independent work opportunities. Sometimes at the end of the course sometimes during leisure time activities classes... I give her extra tasks after school. I give design studies on course topics. I assign one or two of these in two weeks period. [CT4]

I provide (independent work) opportunities, although not very often. Because these students show their creativity without much guidance. They usually ask for suggestions. If they don't have any suggestions, I give them a different activity. I usually give research tasks for them. I need to warn them when they deal with their own materials during the rest of the time in classes. Usually, reinforcement activities can be unchallenging to them. I try to prevent them from getting bored by asking questions. I have additional tasks for them after school. These are repetitions and reinforcement of the lessons taught during the day. I give these almost every day. [CT3]

They deal with their own materials, though not very often, during the processing of unchallenging topics. I welcome that. It is important that they feel happy in class. I sometimes make use of the remaining time from the activities by assigning them a new task. If time does not allow, I let them do an activity (like reading an unfinished book) of their choice without distracting their friends. Generally, I give research, short dictation, repetition, cut and paste, reading, drama assignments, etc. I give about 20 or 30-minute assignments each day after school to help them prepare for the next day or to review the current day. [CT2]

\section{Knowledge-Orientedness}

One of the classroom teachers pointed out that the progress of the course was evaluated from a knowledge-oriented perspective. He also stated that he structured the process accordingly. However, the fact that the whole class is treated as a single student shows that the gifted one counts on the ground by having to be repeatedly exposed to what he/she already knew.

I adjust the duration of the applications related to the course for which we have moved onto new content in light of how much the student knows about the subject. I focus on what they already know for a shorter time and what they don't for a longer time. [CT4] 


\section{Lack of Motivation}

One of the classroom teachers stated that being a gifted student in the regular classroom negatively influences his/her talent development. She also underpinned that she could not be efficient enough in this process and she even pinpointed that this situation had unwanted effects on the other students. It can be argued that this attitude of the teacher may constitute an obstacle for talent development.

I think gifted students become blunted in regular classrooms. My attempts with all my positive intentions are not adequate; other students develop envy. This is even taken as discrimination among students. [CT2]

\section{Polling the Preliminary Knowledge}

Classroom teachers stated that the prior knowledge of what is to be taught involves only previous learning of that. However, it was understood that it was not checked whether the student already knew anything about the subject matter. This shortcoming will make the gifted students repeat what they already knew at the beginning of the class during the introduction/presentation stage.

I ask questions to check their preliminary knowledge, make them repeat the previous lower level objectives and ask them to give examples from their daily lives, etc... I usually do a preview targeting their preliminary knowledge. I think it makes the comprehension of the upcoming objective easier. I do this more in life science, science, and math classes. [CT2]

I do it for every new subject. If it is understood, I will repeat it briefly. For example, through checking the rhythmic counting skills as they begin to multiply.... [CT3]

\section{Individualization}

Even though there are gifted students in the classroom, it was revealed that teachers continue their education addressing the average student level without individualization. It was also understood that they implement individual activities not going out of the frame of age, class level or teaching objectives without focusing on individual differences and needs. This causes the gifted students, who have individual needs, to wait and not receive the necessary individualized support.

Sometimes it can be 10-20 minutes for a presentation or a lesson. It depends on the importance of the issue. In my teaching practices, I assign student tasks at the end of the course. I give a lecture on the subject and make them learn. Then I assign tasks to reinforce what has been learned. [CT1]

Since the activities are within the MEB resources, I do not conduct a preliminary audit. If I prepare the activity from other sources, I value its suitability. [...] I supervise the suitability of individual activities. I make sure that the activity is appropriate to the (general) level and is understandable. [CT2]

The time I spend on individual support does not exceed 15 minutes of a lesson. While other students are doing an activity, I can usually provide individual support for lowerlevel students. [...] I pay attention to level of the tasks I assign individually. [CT3]

I conduct a preliminary audit of the suitability of individual activities. I examine in advance whether it is appropriate to address teaching objectives and students' level. [CT4] 


\section{Grouping}

Classroom teachers underlined that they could not have group work activities/different interaction patterns and that they could not sufficiently focus on collaborative tasks. They also stated that physical environment deficiencies were effective in this. From time to time, they try to go for this option outside school. Owing to that grouping, which is one of the crucial options in supporting the gifted in the classroom environment, cannot be implemented causing the educational process to continue as normal.

I can conduct group work in physical education and play classes, and drama studies. Since I cannot change the seating arrangement, it is not possible in other classes. I cannot really do group work activities. I rarely advise them to meet and work outside the school. Guided by their families... [CT1]

I cannot do enough group work activities. However, my assignments are directed towards collaborative learning. In this case, co-operation is facilitated. [CT2]

I can rarely carry out group work. This is due to the physical structure of the classroom and the lack of opportunities to work together outside of the school. Usually in visual arts classes in the classroom this is done. [CT3]

\section{Teaching Model}

It was found out that classroom teachers did not have a specific teaching model and instead resort to various teaching techniques in their classrooms. They also described this as a teaching model. It is also noteworthy that there is no specific method, technique or teaching model used in the education of gifted students. Failure to use methods or techniques for the education of the gifted will also cause the student to waste his/her time without receiving appropriate training and support.

I use methods like polling the preliminary knowledge, presentation on smart board, reading, dramatizing, brainstorming, sampling, taking notes. I think they attain the teaching objectives better (in this way). [CT2]

Preparation for the subject. Presentation with visuals, videos. Lectures, case studies. Exercise, evaluation. reinforcement. [CT3]

In each lesson, I exploit different teaching models according to the achievement and course status such as being a model, demonstration, play, invention, expression, questionanswer, experiment, educational game, trip-observation, creative writing, station technique, drama, invention, research, exploration, experiencing, etc... [CT4]

\section{Discussion \& Conclusion}

With this research study, different factors that are influential in the phenomenon of waiting in the class were revealed by examining the phenomenon from the perspective of the classroom teacher. Nineteen different codes were obtained under four themes. Among these themes, state of the classroom and intraclass routines themes and codes of early finishing, grouping, teaching model and polling the preliminary knowledge are similar to the ones in Peine and Coleman's (2010) research. Apart from these themes and codes, two different themes and seventeen different codes were revealed. Themes of teacher's competence and the nature of being gifted, as well as the different codes under these themes, led to different findings regarding the causes of the phenomenon of waiting in the class. These include, in 
particular, overcrowded class in a poor physical environment, becoming activated, course content, assessment, boredom, self-distraction, improvisations and individualization, which were mentioned by the majority of classroom teachers.

Although each of the four uncovered themes constitutes critical situations themselves, the theme of teacher's competence and the nature of being gifted are more extensive because of encompassing student and teacher-centered reasons. The teacher's competence theme is one that relates to teacher characteristics and both general and specific field competencies. Researchers highlighted that there are some obstacles to supporting gifted students such as teacher's attitudes and beliefs about learning, ability to differentiate the curriculum and lack of related pedagogical skills (VanTassel-Baska \& Stambaugh, 2005) and teachers need to have been trained and to be encouraged to cooperate with experts in the field (Mosse, 2003). The experiences of the classroom teachers who participated in this research concerning their educational practices also pointed out the need to gain specific competencies. In this respect, findings of the current study are in line with VanTassel-Baska and Johnsen's (2007) and Akar's $(2015 ; 2018 ; 2020)$.

The theme of the nature of being gifted is related to the reflection of some specific characteristics of the gifted over the educational environment. It is in line with the research of Peine and Coleman (2010), especially in terms of rapid and early completion of the given tasks by the gifted students and the development of self-distracting engagements. Gifted students need to be brought together with differentiated and/or enriched tasks or activities prepared for themselves. It is also of crucial importance that rapid learning, which CT2 of this study stressed, has some negative effects on the other students in the classroom. From this point of view, it should be reiterated that the characteristic of rapid learning of the gifted student should be taken seriously not only in terms of developing his/her ability, but also with regard to preventing negative effects on other students.

The theme of state of the classroom is related to some variables that constitute the classroom and affect the course of education. In particular the presence of overcrowded classrooms in a physically insufficient environment was accentuated by the classroom teachers. They agree that the large number of students in their classrooms is a hindrance to supporting the gifted students. Previously, for the ideal number of students with special needs in a classroom, it was stated that "... could not exceed 25 students if there is only one student with special needs in the classroom; and it could not exceed 35 students if there are two students with special needs in the classroom." (MEB, 2006). However, recently, the maximum number of students with special needs (not the size of the classroom though) in the classroom have begun to be revisited, with the amendments made by the MEB (2018a): "...have to be placed equally in classrooms and shall not exceed 2 students with special needs in each classroom." When the experiences of participant teachers are examined, it is observed that formal arrangements cannot be made addressing classroom sizes or students with special needs. Thereupon, the current situation necessitates urgent planning on the part of the policy makers and the stakeholders.

The theme of intraclass routines is a reflection of the practices that teachers perform routinely during classes. From the beginning of a forty-five-minute class, it is striking that the gifted student is subjected to waiting for up to twenty-five minutes to become activated. Given that gifted students are often confronted with being presented with what they already know (Gallagher, Harradine \& Coleman, 1997), then the time they waste during each school day seems too critical to be underestimated. As a matter of fact, calculating the waiting time in the 
environments in which these students are exposed to waiting, and scientifically revealing the student's time loss can bring results that are more striking. Also, the time allocated to lowerlevel students for individual support during courses, which is also consistent with Armstrong's (1995) research findings, demonstrates that gifted students should benefit from resource rooms in parallel with their talented areas/classes; especially in classroom environments where the classroom size is too big and the student levels vary like the ones in this research.

In addition to this, the fact that differing interaction patterns cannot be possible through group work triggers the phenomenon of waiting in the class. Creating different level or ability groups in the education of gifted students has different effects on students (Tieso, 2003). One of these, the intraclass level/ability groups, appears to be a practical option to contribute to the progress of students at different levels at their own pace. When this is considered within the context of the type of education (full-time or dual), the realm of classroom sizes and physical facilities; apart from this type of grouping, it is understood that even group work cannot be paid much attention in general terms. Thence, it can be proclaimed that the classroom teacher needs to gain a significant competency to implement the level/ability groupings first in the classroom and then at the school. This competency, which Akar $(2015 ; 2018 ; 2020)$ too enunciated, can be seen as effective in preventing a gifted student from being exposed to the phenomenon of waiting in the class.

The importance of this research lies in the examination of the reasons for the phenomenon of waiting in the class from the perspective of teachers. In the literature, no research has been encountered except for one where the phenomenon was revealed through grounded theory (Peine \& Coleman, 2010). In this context, examining the phenomenon with qualitative research from a different perspective made it easier to understand the conditions of the teacher. Although the participants of the current study consisted of classroom teachers, it is important that different reasons of the phenomenon can be uncovered by examining the phenomenon from the teacher's vantage point. Consequently, this current research disclosed that there are diverse factors that cause waiting in the class. This research study also showed that when the phenomenon viewed and examined from different perspectives, varied underlying reasons could be discovered.

\section{Implications}

There is a need to lighten the teacher's burden by reducing the classroom sizes where there are special/talented students to more reasonable levels. Intraclass and intraschool level/ability groups can be formed to prevent students from waiting in the classroom. Further to that, the student's exposure to waiting in the class should be taken into consideration in making decisions on grade skipping by delving into this acceleration option during primary school years. It is thought that designing classrooms as a living environment for students bearing in mind their needs rather than keeping them non-tailor made will contribute to the development of abilities of all students- not merely the gifted ones. By creating different classroom types (regular classroom in which gifted students are supported, where students with learning difficulties are monitored and so on), the integration process can become teacher/student friendly. It is vital to evaluate this phenomenon carefully, by considering it in the context of each classroom: classroom teacher and school, before the inclusion process of the gifted and then to implement the practices. It is suggested that general and field competencies are assured before gaining domain specific competencies for the classroom teacher. It would also be better to ensure that regular education environments, in which gifted students will be supported, be organized/reorganized and prepared based on the existing 
legislations and students' needs. To activate the resource room education option-as a compulsory practice for gifted students and the ones with special needs-to be able to meet individual needs by taking them from particular courses, can be helpful for them to perform at a more advanced level compared to their peers.

Developing an inventory to identify situations that may cause the waiting in the class and using it in schools may accelerate pre-inclusion phase and positively affect following phases in this process. Research to be conducted at different levels; elementary, middle, secondary or even preschool may assist in unveiling reasons behind this phenomenon. Different reasons for waiting in the class can also be dwelled upon from the perspectives of school administrators, other branch teachers, parents, gifted and even non-gifted students in the classroom. Short and longer-term effects of being exposed to waiting in the class for gifted students can be a paramount domain of research awaiting to be scrutinized.

\section{Limitations}

This study is the one that aims to understand the reasons of the phenomenon from different perspectives by looking at the in-class waiting experiences of gifted students from the perspective of teachers. On account of the nature of qualitative research, no generalization is intended. Current research was conducted at a public elementary school in a city on the Black Sea Region of Turkey. This city is below the average of Turkey in terms of education, healthcare and economics. The school is above the city average in respect to its demographic characteristics.

\section{Acknowledgements}

A part of this study was presented at the $6^{\text {th }}$ National Conference on Gifted Education (VI. Ulusal Üstün Yeteneklilerin Eğitimi Kongresi) in Istanbul, Turkey. 


\section{References}

Akar, İ. (2015). Üstün yetenekli ögrencileri genel ĕgitim sinıfinda destekleyecek bir sinıf ögretmeninin sahip olmasl gereken yeterlikler [Competencies for a classroom teacher to support gifted students in the regular classrooms] (Publication no. 2015/2301). [Doctoral dissertation, Hacettepe University, Institute of Educational Sciences]. Hacettepe University Library.

Akar, İ. (2018). Üstün yetenekli öğrencilerin genel eğitim sınıflarında desteklenmeleri [Supporting gifted students in the regular classrooms]. In F. Şahin (Ed.), Özel Yetenekli Ögrenciler ve Ë̆itimleri [Gifted Students and Their Education] (pp. 317340). Ankara: Anı Publishing.

Akar, İ. (2020). Consensus on the competencies for a classroom teacher to support gifted students in the regular classroom: A Delphi study. International Journal of Progressive Education, 16(1), 67-83.

Armstrong, D. C. (1995). The use of Kinetic School Drawings to explore the educational preferences of gifted students. Journal for the Education of the Gifted, 18(4), 410-439.

Berman, K. M., Schultz, R. A., \& Weber, C. L. (2012). A lack of awareness and emphasis in preservice teacher training: Preconceived beliefs about the gifted and talented. Gifted Child Today, 35(1), 18-26.

Cohen, J. (1960). A coefficient of agreement for nominal scales. Educational and psychological measurement, 20(1), 37-46.

Coleman, L. J., \& Cross, T. L. (2005). Being gifted in school: An introduction to development, guidance, and teaching. Waco, TX: Prufrock Press.

Creswell, J., W. (2013). Qualitative inquiry \& research methods: Choosing among five approaches. (3rd edition). Thousand Oaks, CA: Sage.

Cullingford, C. (1991). The inner world of the school: Children's ideas about schools. London, UK: Cassell Educational.

Delisle, J. R., Whitmore, J. R., \& Ambrose, R. P. (1987). Preventing discipline problems with gifted students. Teaching Exceptional Children, 19(4), 32.

Gagné, F. (2005). From noncompetence to exceptional talent: Exploring the range of academic achievement within and between grade levels. Gifted Child Quarterly, 49(2), 139-153.

Gallagher, J., Harradine, C. C., \& Coleman, M. R. (1997). Challenge or boredom? Gifted students' views on their schooling. Roeper Review, 19(3), 132-136.

McHugh, M. L. (2012). Interrater reliability: the kappa statistic. Biochemia medica, 22(3), 276-282.

MEB. (1956). Güzel sanatlarda fevkalade istidat gösteren çocukların devlet tarafından yetiştirilmesi hakkında kanun [Law on the upbringing of children with exceptional care in fine arts]. Retrieved October 15, 2019, from https://www.mevzuat.gov.tr/MevzuatMetin/1.3.6660.pdf.

MEB. (1961). İlköğretim ve eğitim kanunu [Primary education and education law]. Retrieved October 15, 2019, from https://www.mevzuat.gov.tr/MevzuatMetin/1.4.222.pdf.

MEB. (1973). Milli eğitim temel kanunu [National education basic law]. Retrieved October 15, 2019, from https://www.mevzuat.gov.tr/MevzuatMetin/1.5.1739.pdf.

MEB. (1997). Özel eğitim hakkında kanun hükmünde kararname [Decree law on special education]. $\quad$ Retrieved October 15, 2019, from https://www.mevzuat.gov.tr/MevzuatMetin/4.5.573.pdf. 
MEB. (2006). Özel eğitim hizmetleri yönetmeliği [Special education services regulation]. Retrieved October $\quad 15, \quad 2019, \quad$ from https://www.resmigazete.gov.tr/eskiler/2006/05/20060531-2.htm.

MEB. (2012). Milli eğitim bakanlığı özel eğitim kurumları yönetmeliği [Ministry of National Education special education institutions regulation]. Retrieved October 15, 2019, from https://ookgm.meb.gov.tr/meb_iys_dosyalar/2019_09/06103840_Ozel_EYitim_Kuru mlarY_YonetmeliYi.pdf.

MEB. (2013). Milli eğitim bakanlı̆̆1 ortaöğretim kurumları yönetmeliği [Ministry of national education regulation of secondary education institutions]. Retrieved October 15, 2019, from

https://ogm.meb.gov.tr/meb_iys_dosyalar/2017_09/20161748_MYLLY_EYYTYM_B AKANLIYI ORTAYYRETYM KURUMLARI YYNETMELYYY.pdf.

MEB. (2014). Milli eğitim bakanlığı okul öncesi eğitim ve ilköğretim kurumları yönetmeliği [Ministry of national education, preschool education and primary education institutions regulation]. Retrieved October 15, 2019, from https://www.mevzuat.gov.tr/Metin.Aspx?MevzuatKod=7.5.19942\&MevzuatIliski=0\& sourceXmlSearch $=\mathrm{Okul} \% 20 \% \mathrm{C} 3 \% 96$ ncesi.

MEB. (2016). Bilim ve sanat merkezleri yönergesi [Science and arts centers directive]. Retrieved October 15, 2019, from https://orgm.meb.gov.tr/meb_iys_dosyalar/2016_10/07031350_bilsem_yonergesi.pdf.

MEB. (2017). Milli eğitim bakanlığ rehberlik hizmetleri yönetmeliği. Retrieved October 15, 2019 , from http://orgm.meb.gov.tr/meb iys dosyalar/2017 11/10113305 yeni rehbrlk yon.pdf.

MEB. (2018a). Özel eğitim hizmetleri yönetmeliği [S̄pecial education services regulation]. Retrieved October $\quad 15, \quad 2019, \quad$ from https://www.resmigazete.gov.tr/eskiler/2018/07/20180707-8.htm.

MEB. (2018b). Bilim ve sanat merkezleri öğrenci tanılama ve yerleştirme kılavuzu 20182019 [Science and art centers student identification and placement guide 2018-2019]. Retrieved October 15, 2019, from https://orgm.meb.gov.tr/meb_iys_dosyalar/2018_11/09171525_20182019_BYLSEM_YYRENCY_TĀNILAMA_VE_YERLEYTYRME_KILAVUZU.pdf

Mosse, J. L. (2003). The nature of gifted education in the regular education classrooms in the elementary schools of a rural western Pennsylvania school district: Implications for a staff development program. Unpublished Dissertation. University of Pittsburgh.

Peine, M. E. (2003). Doing grounded theory research with gifted students. Journal for the Education of the Gifted, 26(3), 184-200.

Peine, M. E., \& Coleman, L. J. (2010). The phenomenon of waiting in class. Journal for the Education of the Gifted, 34(2), 220-244.

Ross, P. O. C. (1993). National excellence: A case for developing America's talent. US Government Printing Office, Superintendent of Documents, Mail Stop: SSOP, Washington, DC 20402-9328.

Sisk, D. (2009). Myth 13: The regular classroom teacher can "go it alone". Gifted Child Quarterly, 53(4), 269-271.

Tieso, C. L. (2003). Ability grouping is not just tracking anymore. Roeper Review, 26(1), 2936.

VanTassel-Baska, J., \& Stambaugh, T. (2005). Challenges and possibilities for serving gifted learners in the regular classroom. Theory into practice, 44(3), 211-217. 
VanTassel-Baska, J. \& Johnsen, S. K. (2007). Teacher education standards for the field of gifted education: A vision of coherence for personnel preparation in the 21 st century. Gifted Child Quarterly, 51(2), 182-205.

Yang, Y., Gentry, M., \& Choi, Y. O. (2012). Gifted students' perceptions of the regular classes and pull-out programs in South Korea. Journal of Advanced Academics, 23(3), 270-287. 